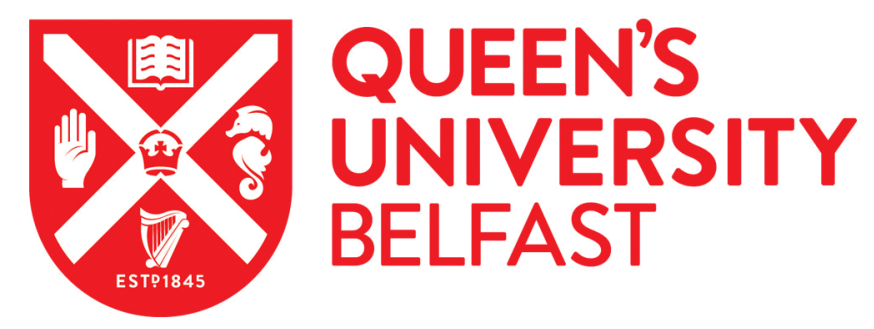

\title{
Planning to stay in the countryside: the insider-advantages of young adults from farm families
}

Stockdale, A., \& Ferguson, S. (2020). Planning to stay in the countryside: the insider-advantages of young adults from farm families. Journal of Rural Studies, 78, 364-371.

Published in:

Journal of Rural Studies

Document Version:

Peer reviewed version

Queen's University Belfast - Research Portal:

Link to publication record in Queen's University Belfast Research Portal

\section{Publisher rights}

Copyright 2020 Elsevier Ltd.

This manuscript is distributed under a Creative Commons Attribution-NonCommercial-NoDerivs License

(https://creativecommons.org/licenses/by-nc-nd/4.0/), which permits distribution and reproduction for non-commercial purposes, provided the author and source are cited.

\section{General rights}

Copyright for the publications made accessible via the Queen's University Belfast Research Portal is retained by the author(s) and / or other copyright owners and it is a condition of accessing these publications that users recognise and abide by the legal requirements associated with these rights.

Take down policy

The Research Portal is Queen's institutional repository that provides access to Queen's research output. Every effort has been made to ensure that content in the Research Portal does not infringe any person's rights, or applicable UK laws. If you discover content in the Research Portal that you believe breaches copyright or violates any law, please contact openaccess@qub.ac.uk. 
Planning to stay in the countryside: The insider-advantages of young adults from farm families

\begin{abstract}
There is growing interest in immobility studies prompted by declining internal migration rates. While recent studies have examined the agency of stayers, this paper sheds light on an overlooked structural influence in a rural context: namely, planning policy on house building in the countryside. Using young adult interview data from a pilot study in rural Northern Ireland we demonstrate a strong place attachment with the home area which is entangled in complex patterns of family history, farm ownership and continuing familial networks. This attachment translates into an equally strong desire to stay, which is enabled through Northern Ireland's different past and present countryside planning policies. A planning presumption in favour of countryside development at specific times has facilitated one-off self-built homes by farm families. Such development is regarded as normal and represents the least expensive route into owner-occupied housing. However, the policy provides young adults from farm families with a considerable insider-advantage when it comes to being able to stay in the countryside and, as a consequence, staying may become the preserve of those from existing farm families.
\end{abstract}

\title{
Key words: immobility/ staying; place attachment; planning and self-builds; Northern Ireland
}

\section{$1 \quad$ Introduction}

The out-migration of young adults from rural areas is a common occurrence, with a 'culture of leaving' or 'needing to move to get on' widely reported (Johansson, 2016; Nugin, 2014). Leaving the parental home and moves specifically for higher education, employment or cohabitation/ marriage frequently lead to an urban destination. A contributory factor is the long-standing rural allegation of 'no homes for locals' (Shucksmith, 1981): those who wish to stay have little option but to move to larger settlements where new and more affordable housing, employment opportunities and services, are increasingly concentrated. Such issues have dominated the academic literature, however, there is a growing interest in those who stay (Clark and Lisowski, 2019; Cooke 2011; Cresswell 2012; Stockdale and Haartsen, 2018). The focus of these studies is on the decision-making or agency of stayers (Haartsen and Stockdale, 2018; Hjalm, 2014) which inadvertently overlook, and accordingly underplay, the importance of structural influences on staying. To be able to stay, there must be opportunities to do so. In this paper, we specifically consider rural housing opportunities and allege that planning policy is an important, yet rarely recognised, structural influence on staying. By doing so, we draw together two bodies of knowledge: we link the population geography and planning 
literatures to build on earlier work which highlights the role of the local context on migration trends (Stockdale and Catney, 2014), links a diverse set of residential mobilities to house building (Gkartzios and Scott, 2010), and demonstrates notably different planning approaches to house building in rural areas (Gkartzios and Shucksmith, 2015; Gallent and Scott, 2019). While an urban containment stance has dominated in Great Britain, Northern Ireland has adopted a more liberal planning approach during specific time periods. Rural one-off house building is common, as in the Republic of Ireland, and has been studied in the planning literature (Gkartzios and Shucksmith, 2015). Here we link it to the population geography literature, and specifically that on rural immobility, to shed new insights into the role of planning as a structural influence on staying.

The rest of the paper is organised into four parts. First, we explore (im)mobility and planning in a rural context. We review the emergent literature on rural staying and highlight the importance of place attachment and senses of belonging. This is followed by an overview of the UK's countryside protectionist approach, including the more liberal policy adopted in Northern Ireland. We allege that planning is perhaps an agent for both rural decline and community sustainability, and in relation to the latter suggest that the insider-advantage theory of immobility (Fischer and Malmberg, 2001) is a useful lens through which to unpack structural influences on staying by rural young adults. Second, we introduce empirical aspects to the research, namely qualitative interviews with young adult stayers in rural Northern Ireland. These interviews concentrated on the decision to stay, and in the course of these discussions, the role of self-build houses emerged as important. Third, the analysis focuses on the existence of deep family farming roots which create a strong desire to stay, and a planning approach which provides an important 'ticket to stay' among those from farm families. Finally, in the conclusion we contend that planning can either represent a significant structural enabler or obstacle to immobility/ staying and call on researchers to investigate more fully other structural influences to provide a nuanced understanding of immobility/ staying.

\section{$2 \quad$ Planning as an agent for rural decline and community sustainability}

\section{A growing interest in immobility/ staying}

Many rural communities are increasingly characterised by decline, both population decline, along with its associated population ageing, and service decline. At the same time, the population literature displays a dominant migration discourse (Barcus and Halfacree, 2018; Hjalm, 2014) and the rural population literature specifically notes that different migration flows dominate in rural settings across the life course (Ni Laoire and Stockdale, 2016). Those who do not move (that is, the immobile or stayers) are frequently portrayed as a residual category, having 'failed to leave' or been 'left 
behind' (Looker and Naylor, 2009; Nugin, 2014). This negativity to, and lack of attention on, staying is surprising. In today's sustainability policy arena, retaining residents, including young adults, would seem crucial to the long-term sustainability of rural communities (Kanakis et al., 2019). In addition, immobility or staying is 'a strong and persistent behavioural strategy for a large majority of population' (Fischer et al., 2000: 3). Recent research continues to highlight this (Champion and Shuttleworth, 2017; Cooke, 2011; Coulter et al., 2016). Population geography has therefore concentrated on a minority process (migration) and largely ignored the more dominant immobility/ staying. Equally, the planning literature has largely overlooked the potentially significant contribution that stayers can make in delivering sustainable rural communities.

Hjalm's (2014) seminal investigation of stayers in an urban context and Stockdale and Haartsen's (2018) later rural focus did much to bring immobility, staying and stayers into the lens of population and rural geography. Most notable, staying is no longer viewed as '... a wasted moment or a kind of emptiness and inactivity' (Creswell, 2012: 648). Rather it involves active and informed choices: studies distinguish between those who stay through personal choice or as an outcome of certain constraints (Barcus and Brunn, 2009; Coulter et al., 2016; Fernandez-Carro and Evandrou, 2014; Morse and Mudgett, 2018; Stockdale et al., 2018). They acknowledge both individual considerations and the structural context (such as, employment opportunities) in which these complex decisions are made. For example, Coulter et al. (2016) call for residential mobility and immobility to be reconceptualised as relational practices that link lives through time and space while connecting people to structural conditions. Although acknowledged, structural influences are rarely investigated. Petrin et al. (2014) and Thissen et al. (2010) report that aspirations to stay or leave are shaped by perceived employment opportunities in the local labour market. However, the labour market itself is not examined through a staying lens. Moreover, it is young adults' residential aspirations and migration intentions that are frequently examined. Few studies, by contrast, examine the role of specific structural factors in the decision-making of actual stayers.

Other strands of the staying literature emphasise the important role of family (Tucker et al., 2013), community (Mellander et al., 2011) and the area's physical characteristics (Haukanes, 2013). In the words of Wolfe et al. (2019: 18) young stayers 'feel a strong sense of membership and emotional connection to the community'. Factors consistently reported as important are place attachment and belonging (Clark et al., 2017; Leopold et al., 2012; Stockdale et al., 2018). Place attachment (see Lewicka, 2011 for an overview) may be because of family roots, memories, a sense of home, social factors (family and/or friendship ties, sense of community), physical or natural qualities (wilderness, 
aesthetic), or residential familiarisation. Attachment has been shown to be to a region, an area or locality, a landscape (Barcus \& Brunn, 2010; Hidalgo \& Hernandez, 2001), or an ancestral home (Roin, 2015). Relph (1976) claims that 'existential insidedness' is the highest level of place attachment and is associated with families who have lived in an area for multiple generations. Similarly, Lewicka (2011: 215) alleges that 'a true sense of place can be developed only by those who have been raised in the place or lived there for many generations'. Savage and colleagues present several narratives of belonging to place (Savage et al., 2005; Savage, 2010): nostalgia (longing for lost values associated with former times), dwelling (homing practices whereby the individual passively identifies with their home place), and elective belonging (the place of residence is chosen). We expect a dwelling narrative of belonging to feature among young stayers in a rural context which is supported by 'existential insidedness'. Moreover, we suggest that this level of place attachment is likely to be intensified among farm families. Deep family farming roots (where the same land has been farmed by their ancestors) are likely to generate a strong sense of home and, in turn, a strong desire to stay. Equally, extensive kinship networks in the area further introduce a resistance to moving (Johnston, 1971) and, separately or together, a reference space (where ancestors once lived) and a founding space (residential familiarisation) strengthen senses of belonging (Rérat, 2014). Moreover, the children of farmers frequently view the countryside in idyllic terms (Rye, 2006). What is missing, however, is anything more than a general recognition that in order for someone to stay, there have to be place-specific opportunities (housing, employment, services) to stay (Kuhmonen et al., 2016). In this paper, we focus on housing opportunities.

\section{Contrasting approaches to house building in the countryside: A 'ticket to stay'?}

Housing development in the United Kingdom is controlled by a statutory land-use planning system whereby planning permission is a requirement. Since 1947, the UK has operated a policy of urban containment and consequently a presumption against development in the countryside. Today's (England) National Planning Policy Framework (2019) continues this emphasis, stating that '[p]lanning policies and decisions should avoid the development of isolated homes in the countryside ....'(para. 79). Urban containment was initially justified on the grounds of protecting farmland for food production, and then for rural landscape and environmental reasons, and later for the delivery of sustainability goals (Gkartzios and Shucksmith, 2015). But such an approach is alleged to privilege landscape protection and environmental concerns over the social and economic dimensions of sustainable rural communities (Hall et al., 1973; Scott, 2019). Taylor (2008: 45) speaks of a 'sustainability trap' and Scott and Murray (2009: 756) cite 'a policy disconnect ... between environmental and landscape objectives and goals that support the social, economic and cultural 
imperatives of rural communities ... with planners [giving] limited reference to the notion of sustainable communities'. By limiting the supply of new homes in rural areas, planning has contributed to the unintended and contentious issue of affordable homes. Shucksmith (2011) asserts that planners are agents of gentrification, and Gkartzios and Shucksmith (2015) report the emergence of a 'spatial apartheid' where limited housing supply, accompanied by spiralling house prices, has led to a rural residence becoming attainable to too few. These processes are likely to disproportionally affect first-time home buyers such as young adults. Indeed, 'without a cross-section of people living in the countryside, rural economies cannot function and key services cannot be provided ... Housing access is thought to play a pivotal role in sustaining the life-cycle of [rural] communities ...'. (Gallent and Scott, 2019: 265 and 268).

In contrast to the 70 years of uninterrupted restrictive rural planning policy operating in the rest of the UK, the Northern Ireland approach to countryside development has been schizophrenic in nature. A strong presumption against such development was replaced by a more liberal planning regime (including for one-off housing in the countryside) in the 1980s and 1990s, only for the planning pendulum to swing back towards stronger countryside controls since 2006. Such fluctuations in approach demonstrate an on-going struggle to reconcile the economic, social and environmental elements of rural sustainability alongside Northern Ireland's very different system of land tenure (compared to elsewhere in the UK), and an associated 'cultural predisposition to living in the countryside' (Scott and Murray, 2009: 261).

Northern Ireland's dispersed settlement pattern, comprised of small rural settlements and single dwellings in the open-countryside, emanates from various Land Acts (1885-1925). These Acts divided large landed estates, and enabled tenants to purchase land holdings, creating the small owneroccupied family farm structure (Hunter, 1987) that remains today. While many rural residents are unconnected to farming (as a result of agricultural transformation), much land remains in the family and is either farmed part-time or as a hobby (in addition to off-farm employment), or let to neighbouring farmers under a conacre system. '[L]and has been in their families for generations and they feel duty bound to follow tradition and ensure that ownership remains in the family' (Heenan, 2011: 478). Many residents, therefore, '... have family roots in the locality that are underpinned by history and memory, a strong attachment to place, ....' (Scott and Murray, 2009: 760-761).

Just like in the rest of the UK, Northern Ireland's first regional plan (Matthew, 1964) and Development Control Policy Note (DoE, 1976) emphasised urban containment: anyone seeking 
planning permission for a new dwelling in the countryside was required to prove an employment need to live there. Subsequently, a government committee (Cockcroft 1978) was highly critical, claiming that this policy exacerbated rural population decline and called for a more relaxed approach to rural housing development to be adopted. This call was endorsed (DoE, 1978) with new policy differentiating between 'areas of special control' where development was to be restricted to 'proven need', and the remainder of the countryside where a more permissive approach operated. This too was criticised. First, on environmental grounds with a suburbanisation of rural areas alleged and, second, that the policy in special control areas was open to abuse (houses approved on the basis of 'need' were subsequently sold at inflated prices). Such criticisms prompted a further policy revision (DoE, 1993) which heralded in a period when the general planning presumption was in favour of countryside development: permission for one-off houses was generally secured as long as the proposed development met detailed criteria (for example, on siting, design and landscaping). The impact was immediate and dramatic. In the previous year some 1800 planning applications were approved for single new dwellings; by 2002-03 this had increased to 5300 per annum. At its height, during the period 2004-06, 14,000 new countryside dwellings were permitted, treble that for England, Scotland and Wales combined. It is no coincidence that this exponential increase in the number of approved planning applications for a house in the countryside corresponded with a period when the NI property market (as elsewhere) was especially buoyant (up to the 2008 economic recession): put simply, a self-build on family owned farmland represented the most affordable route into owner-occupation (Clinch et al., 2002). Such levels of development were perceived as unsustainable and damaging to the landscape: similar one-off housing in the Republic of Ireland has been described as 'spatial anarchy' (Gkartzios and Shucksmith, 2015). In Northern Ireland, the planning pendulum duly swung back to a presumption against such development (DoE 2007 and 2008; SPPS 2015) with today's sustainable development strategy '... to manage development in a manner which strikes a balance between protection of the environment from inappropriate development, while supporting and sustaining rural communities' (SPPS, 2015: 51). It restricts the number of new builds on a farm to one every ten years (subject to specific criteria) and, in doing so, reduces the number of young adults who can avail of this route into owner-occupied housing.

Notwithstanding this radical recent shift in policy, viewed within the context of staying in rural areas, Northern Ireland's approach to countryside house building has offered in the past, and arguably continues to offer to a lesser degree, a potential advantage to those from farm families. Indeed, as a result of this favourable planning climate '... in [NI] rural culture the offering of a [building] site to a newly married couple has long been regarded as almost an obligation' (Sterrett, 2003: 139). The 
insider-advantage theory of immobility (Fischer et al., 2000; Fischer and Malmberg, 2001) is relevant here. It contends that certain individual abilities and assets are location specific: they can only be used, or only exist, in a specific place. Consequently, 'immobility is a utility maximising strategy to a majority of people... [m]obility generally induces the loss of most of these abilities and assets and requires new investments in obtaining a 'ticket to entry' at a new place of residence' (Fischer et al., 2000: 10 and 11). While Fischer's study is based on Swedish labour markets, we contend that the insider-advantage theory is relevant to housing markets too, and especially the rural self-build sector in Northern Ireland. The option of a building site is place- and time-specific: it will only exist on the family farm, and at a time when planning is favourable to one-off housing in the countryside. When these combine, they potentially deliver a 'ticket to enter' not only the housing market but specifically the rural owner-occupier housing market, and potentially offer a 'ticket to stay' in rural areas for those from farm families who otherwise might be 'forced' to leave because of a lack of affordable housing. In the remainder of this paper, we seek to explore whether the planning approach in Northern Ireland, while not deliberately intending to do so, gives young adults from farm families an insider-advantage to be able to stay by virtue of their access to building sites. To the best of our knowledge, no other study has explored the causal link between rural planning and staying.

\section{$3 \quad$ Methodology}

Our data comes from a pilot study which sought to examine the diverse staying processes of rural young adults in the Clogher Valley area of County Tyrone, Northern Ireland. The area shares a border with the Republic of Ireland and is reached by car heading west from Belfast in approximately 90 minutes. The area is a mosaic of small towns (such as Fivemiletown and Clogher), villages and hamlets (Eskra and Newtownsaville), and a sizeable dispersed population living in the open countryside linked to, in many cases, small family farms. The Clogher Valley has a low population density (43 persons $/ \mathrm{km}^{2}$ ). Residents are dependent on nearby (30-minute drive) regional centres (Dungannon, Enniskillen and Omagh) for employment and public services. The area has a tradition of youth out-migration for higher education and employment.

Interviews were undertaken with fifteen young adult stayers (aged 18-30): we acknowledge that this number is insufficient to provide a comprehensive analysis. Instead, this was an exploratory study to identify key themes informing the staying process (which subsequently fed into an ongoing larger research project). Stayers are defined as those who continue to live in the area (Clogher Valley) in which they spent their childhood. They were recruited via appeals in local newspapers and on social 
media, contacts with local groups (e.g. churches and sports clubs), posters inviting volunteers, and snowballing where some interviewees recruited a friend to also participate.

Nine one-to-one (five males and four females) and three joint interviews (involving both partners) were undertaken. All but one (at a nearby hotel) were conducted in the interviewee's home and followed a semi-structured in-depth format. Each was conducted by a young female researcher and covered a range of topics: most relevant to the focus of this paper was the individual's stayingrelated decision-making and experiences of the rural home area. All interviews were recorded and later professionally transcribed. The analysis involved close reading and re-reading of the transcripts by the authors, with key themes emerging as part of an iterative analytical process. While it was the stayers' agency in the decision-making process that was being explored, the importance of rural planning as a structural influence emerged as an important theme. This is especially pertinent given that none of the young adults had as yet built a one-off house, however, as will be shown, all had definite plans to do so, and several continued to live in their parental self-built home. Interview excerpts use a pseudonym. All of the interviewees possess a connection to family farming; either having grown up on a farm, currently 'farm a bit' themselves, or own small parcels of land that they rent to neighbouring farmers. We did not intentionally target those from farm backgrounds: instead, their dominance in the sample is indicative of the strong continuing links to land ownership among Northern Ireland's rural families. Despite this, only one interviewee is a full-time farmer: Daniel runs a mixed cattle herd with his father. The others all have off-farm jobs - in the education, health and social services, hospitality, and financial services sectors, or are employed in a trade. Most commute daily to nearby regional centres. Each's individual agency in terms of the decision to stay is explored elsewhere (Stockdale et al., 2018). Here we examine the multiple dimensions of place attachment evident, and how these translate into a desire to stay, before progressing to consider the specific role of self-builds as a 'ticket to stay' in the countryside.

\section{Deep family farming roots create a strong desire to stay}

According to the literature reviewed earlier, those who stay display strong place attachment and senses of belonging. This is supported by our interviewees. Multiple generations of their families have lived in the Clogher Valley. Where there is a 'culture of leaving', as is the case in this area, retaining young adults with a long family association with the area is important for the community's sustainability. Unlike other studies, however, we find that attachment to the Clogher Valley is entwined with deep family and farm roots in the area. 
Several allege that living in the Clogher Valley 'is just a family thing' (Amy) and that 'you feel rooted because you've always lived here' (Rachel). Aspects of Rérat's (2014) reference and founding spaces and Relph's (1976) existential insidedness are in evidence. It is their family's long association with the Clogher Valley, that they themselves grew up in the area, and their continuing familial networks that underpin their place attachment and firmly anchor our young adults to the area. Take, for example, Sharon and Rory who allege that:

'Both our families have lived in this area for generations - I dunno, hundreds and hundreds of years' (Sharon);

Karen who pointed:

'there's my granny's house - my granny has passed away but my oldest uncle lives there and between there and my house there's another [house] which is my other uncle's. Then my dad's sisters, ... all live within a few miles of here. So everyone is within ... five, ten minutes of each other ... Here is where I want to be ... ';

and David:

'... I have uncles and aunts living just down the road. One of them lives on my father's home farm ... so I suppose we've been connected to this area for a long time'.

Moreover, these interviewees come from established farm families, and can recount their ancestry not only to the area but to a specific family farm:

'We live on my paternal grandfather's farm ... my father grew up here, his father grew up here, and probably his father grew up here .... I grew up here ... so I do feel attached to this place and to the farm' (Shane).

'... my mum and dad live close by, they have a farm and my granny lives on the farm. ... my granny is eighty-six and her whole family was from round here, she grew up on that farm herself' (Amy).

The attachment to a family farm is the more remarkable given that only Daniel is wholly dependent on a farming income. The others while employed in non-farm-related activities, nevertheless, possess a strong attachment to a farm which has been in their family for several generations. This part-time or hobby connection with farming is typical of an ongoing Northern Irish rural tradition. Even when the farm is too small to be commercially viable, the family attachment to land and agriculture remains strong. It is as if farming is 'in their blood' and while either the farm size or the individual's desire for another occupation prevents them farming as a commercial enterprise, these young adults nevertheless undertake what Daniel describes as 'a bit of farming'. David helps on his father-in-law's farm:

'I go round and do milking of the cows and feed them silage in the evenings after work'; 
Kieran 'farms as a hobby'; and Karen describes the farm that she works with her father as a 'play farm ... it's like a hobby ... it's not a business as such'. Notwithstanding farming's hobby status, they possess a remarkably strong bond to it. Karen likens it to having children:

'[farming] I suppose it's the equivalent of having a child, you are raising something. Like whenever your calves are born and you rear them so they are a kind of attachment'.

Perhaps farming (however small scale) is a way of keeping a bond between them, the land and previous generations of their family: '[o]ne can move places, but one cannot take one's soil with one, and one cannot make another soil one's own' (Bauman, 1992:684). This bond to past generations might be thought of in terms of Coulter et al.'s (2016) linked lives concept. Continuing to work the same land as one's ancestors - even on a part-time or hobby basis - links the lives of these young stayers to those of their ancestors through time. This is translated into a traditional form of belonging (dwelling) whereby the individual regards not only the Clogher Valley as home, but a particular farm. According to Savage (2010) dwelling is frequently associated with those locally born and bred - as our interviewees are. Note in the following excerpts how explicit links are made to staying and farming, and staying and family members in the area:

'It's where we grew up and we're familiar with it [Clogher Valley]. .. I wouldn't like to ever be away ... I really want to stay here, definitely. Those who stay here .. I'd say they are more family-orientated. They have family in the area. They belong here. It's just home' '(Sharon).

'...the established farming families always stay ... actually it is quite traditional, the fellas [males] have all stayed ... and the girls of those families have all moved to wherever ... ' (Conor).

Even Daniel who is a full-time farmer admitted:

'If the farm wasn't here I probably wouldn't be here. In fairness, the ones that have stayed in this area are involved in agriculture or had an interest in doing a bit of farming'.

While Conor (above) suggests that it is farmers' sons that have mainly stayed, we find so have daughters. For daughters, it is important that their children grow up in a farm environment, just as they themselves had, but also that they have family members nearby (especially parents) to help with raising children:

'.... I'm the only girl [in the family] so I'm going to be closer to my parents anyway. ... I think it will be handy having mum and dad nearby when we start a family. ... I want my children to enjoy daddy's farm as they grow up ....' (Amy).

The importance of an agricultural upbringing is also shared by her husband (David). He observes a more positive work ethic among those from a farm background - 
'It can be as blatant as night and day sometimes. [Those from a farming background] well there is a certain work ethic there instilled from a young age .... it's just been engrained and they don't even realise they have it. ... I want my children to have that'.

Stockdale et al. (2018) suggest that those from farm families may stay because of a perceived obligation to take over a family farm. While this might be a factor for some, such as Daniel, it does not explain why those from farm families with off-farm employment also plan to stay. Several other motivations have been identified including a strong place attachment and senses of belonging to a family farm, an extensive network of family members living nearby, and a preference to raise children in such a location. While these may contribute to a desire to stay, on their own they do not enable someone to stay. To stay there must be the means to do so.

\section{Self-build opportunities as a 'ticket to stay' in the countryside}

In common with the situation in many countryside areas (Gallent and Scott, 2019), housing availability is problematic. Rachel comments:

'It's really hard to get a house in the country ... If I was to go and buy my own house ... I would have to live in a more urban area because I don't think there would be the [housing] availability here ... '.

Rachel went on to reflect on friends who recently got married:

'A lot of them would love to live in the countryside and just aren't able to, just the properties aren't there to buy or rent. ... '.

Rory alleged that purchasing a building site in the area could cost up to $£ 25,000$ and:

'[F]ew young couples could afford that on top of the cost to build'.

Coming from a farm family, however, does offer a certain insider-advantage; namely, upon marriage a building site is frequently offered as a gift (Sterrett, 2003), or if purchased from family members is done so at a considerably reduced rate. Farm families, therefore, subsidise young adults' entry into the housing market and by doing so enable these young people to stay.

'Anyone who has built houses here ... come from the main farming families.... Most people's houses are built by these families' (Niamh).

This is not new. Shane's father built a house on the family farm during the late 1980 s when, following the Cockcroft Report, a more liberal planning approach to new residential development in the countryside was adopted:

'Up until the age of 4, we lived in [a neighbouring small town] - you see dad had to save up to be able to build this house here and he had to wait until he could get planning permission ... it wasn't easy then' (Shane). 
Similarly, Amy's

'Mum and dad built a bungalow on the farm when they got married [in the 1980s]', and Karen explained that her parents first lived in a nearby service centre before building a house on her father's 'home farm' during the late 1990s. For the parents of our young interviewees it was common then to move at union formation to urban centres, where new affordable housing developments were located, until they had saved sufficiently and/or planning policy was favourable to self-build on family-owned land. As Karen reports:

'[W]e were always going to move eventually to here because my dad is originally from this area, ...'.

Planning's presumption in favour of housing development in the countryside during the 1980s and 1990s provided a route by which those from farm families who wished to stay, but previously had to leave because of a lack of rural housing, could return to their home rural area. This insider-advantage possessed by farm families continues today as emphasised by Amy who has plans to build on her parents' land:

'We won't be buying it [building site]. Anyway it would be a gift. I'll be taking it!' and Sharon whose parents have identified a possible site for her and Rory to build on:

'Mum and dad have said, 'if you can get planning permission, it's yours'. We want to try and save up a bit first' (Sharon).

Notwithstanding their access to a building site, this need to save in order to be able to build was repeatedly emphasised. Amy and David, while planning to build in the future, have bought a 'starter' home in a small development in a local settlement. It, Amy describes as:

'.. the more sensible choice for now until we save enough to be able to build [on her father's farm]'.

Amy alleges that the mortgage for her desired self-build would be twice that for their starter home. Having a low mortgage now enables them to adequately save to self-build their ideal home in the future. Indeed, a self-build is a common occurrence:

'I don't know how many of my friends have gotten married and build their own houses. So many of them have just been given [family] land to build on ...' (Sharon).

Kieran notes that this practice continues to bring former out-migrants back to the area, perhaps when they get married, or start a family, or simply have saved enough to be able to self-build:

'A lot of leavers do come back in their thirties and forties to build a house, ... their daddy gives them a [building] plot and they come back'.

To self-build is perceived as normal: 
'It's my mindset, I really want to build my own house. ...That's just the normal way. 'I'd always prefer to build because l'd like to know the layout of my house before it is built ... I'd like to know exactly what my house was going to be, what way it was going to be built and have input in everything that's in it' (Shane).

David and Amy too have thought about the style and size of home they want to build:

'I would like a classic country cottage style I think... It probably would be one storey or a storey and a half I'd imagine' (Amy).

'...it would probably be around two thousand square foot [in size] or something like that' (David).

Similarly:

'The end goal will always be to build ..., you can look at it and be 'that's mine, I made that' ... ' (Clare),

'We've always wanted to build our own place. It's like a landmark thing' (Rory),

'I use computer games to design [my house] ... I love the idea of having my own house the way I want it' (Sharon).

It should be remembered that the purpose of the interviews was to explore the staying process not specifically house building in the countryside. The fact that self-build housing was raised time and time again in different contexts by these young people emphasises its core importance in facilitating them to stay.

The self-build cost is a major consideration. According to Rory, building a house yourself 'would maybe cost $£ 115,000$ ' while Shane puts it higher at ' $£ 150,000$ - that's the going rate to build now'. Either way, this is considerably less than the average $£ 227,476$ purchase price for a detached house in this part of Northern Ireland at the time of the interviews (Ulster University, 2016). It, in turn, is considerably below this area's property market peak in 2007 of $f 319,762$ (Ulster University, 2007). A self-build, especially on family-owned land where a building site is provided as a gift, is the least expensive option to becoming a home owner. The cost can be further reduced through the use of sweat equity:

'Being a tradesman, David [her husband] could do lots of things himself' (Amy),

'Many who build are the sons or daughters of builders or contractors: they have that family resource available to them' (Conor),

and drawing on considerable local social capital: 
'Well on the farm you always have general connections [contacts]. A lot of the ones I went to school with too, the ones that have stayed would be hands-on, they would be [in] trades and that' (Daniel),

'.. we could get mates' rates ... We know contractors and builders' (Rory),

'... most of my friends that I went to school with now are builders or joiners, I have one friend who is an architectural planner ... I suppose it's not what you know but who you know in a rural community ...' (Shane).

The extensive network of friends and family that results from possessing deep family roots in an area clearly provides invaluable resources when contemplating a self-build project.

In planning a self-build home these young interviewees take into account future life stages. The migration literature informs us that the transition from one life stage to another acts as a trigger to move house (Geist and McManus, 2008; Michielin and Mulder, 2008). Here, however, self-builds enable staying in the area for a lifetime. Sharon explained:

'I'd like a storey-and-a-half house, that you could have upstairs while we were fit, but having a bedroom and stuff also on the ground floor as well, so that if in years to come ... [we were] not fit to get up the stairs ... I know it's funny to think about that, isn't it? But you have to when building your own house'.

Likewise, Shane emphatically declared:

'If I'm going to build it has to be a house for life. ... If I'm going to build a house I will stay in it'.

The fact that these young adults are so set on staying, and staying for a lifetime, is important for sustaining rural communities.

\section{$6 \quad$ Discussion and Conclusions}

The contribution of this paper has been to explore immobility or staying by rural young adults through the lens of planning policy. In doing so, we, firstly, have shed new and deeper insights into the role of one specific structural influence on the decision to stay, that of rural residential development policy, and secondly, raised important questions about the potential consequences of such policy for the delivery of sustainable rural communities. We examined staying in terms of place attachment and, in turn, demonstrated the role of self-builds as an important 'ticket to stay' (and return) among those from farm families. We alleged that, as a consequence of past and present rural planning policy, young adults from farm families in Northern Ireland possess a particular insideradvantage when it comes to the ability to stay in their rural home areas. 
The literature on immobility and staying concentrates on the individual agency of stayers. Much less attention is given to structural influences, such as, housing availability. Indeed, the UK's urban containment policy is frequently criticised for its impact on the housing market (including the rural housing market) leading to the emergence of rural areas that have become the preserve of those who can afford to compete in an ever-rising rural property market. Ironically, urban containment is justified within a dominant sustainability discourse. By contrast, the potentially positive contribution of planning to the sustainability of rural communities is rarely reported. Yet the different approach to one-off housing in rural Northern Ireland offers an opportunity for young adults, from farm families especially, to stay in the countryside and thereby contribute to the long-term sustainability of these communities. Arguably, the retention of 'youth' can help stem rural depopulation, population ageing and the often accompanying rural service decline. We acknowledge that in delivering one aspect of sustainability (social dimension), critics will argue that the resulting dispersed rural housing pattern does little for the achievement of national economic or environmental dimensions. Such housing is reported as a blight on the landscape (BBC, 2006) or a 'development free-for-all' (Gallent and Scott, 2019: 264). Yet, viewed from the perspective of rural immobility and staying, the Northern Ireland approach provides an interesting structural influence on the decision to stay. Tying together decisions to stay and structural factors can be an especially fruitful aid to understanding rural demographic processes.

While place attachment and senses of belonging are shown in the literature to be important in the decision to stay (Roin, 2015; Wolfe et al., 2019), the added value of our study is to show that attachment and belonging to the home place is entangled in complex patterns of family history, farm ownership and continuing familial networks. Such patterns translate into a strong desire to stay that is not solely based on the fact that interviewees grew up in the Clogher Valley and therefore are familiar with it. Instead, they stem from deep family roots to local farms. These small farms - often not commercially viable - have been in the family for several generations and represent a much valued link between our young adults and their ancestors. Even though all-but-one have off-farm jobs the majority continue to 'do a bit of farming' and with it retain their own personal connections to ancestors who also farmed the same land. Moreover, all possess an extensive family network in the area so that the ongoing residential pattern closely resembles the traditional Irish clachan system: tiny hamlets or clusters of kinship homes. Being able to self-build on family farmland further embeds this clachan pattern. One might expect similar place attachments and, accordingly, a deep desire to stay too in other rural parts of the UK. However, in contrast to the strict presumption against countryside development elsewhere, Northern Ireland has operated a presumption in favour 
of countryside development at specific times. By doing so, it has introduced the ability to build on family land thus ensuring that the current generation of farm families remain in the area (should they wish). Their access to a (gifted) building site gives them a considerable insider-advantage or 'ticket to stay' over those from non-farm backgrounds. The latter's requirement to purchase a building site is likely to mean that it is only an option for those from well-off non-farm backgrounds. Arguably, Northern Irish rural planning has been as much an enabler, as the rest of the UK's approach has been an obstacle, to staying in the countryside at the young adult life stage. Yet the important role of planning has still to be fully considered in the immobility/ staying literature.

Even though none of those interviewed have as yet self-built, all possess aspirations to do so and a number continue to live in their self-built parental home. The possibility to self-build on family land taps into a particular Northern Irish rural psyche: to build is the 'end goal', 'a landmark thing', 'the normal way'. The self-build is a home for life. It seems to fulfil a deep sense of family-continuity and a strong emotional bond to this family place. Is it because of the smallness and non-commercial viability of many family farms that releasing land for a building site is unproblematic? Rather than being commercially viable as an agricultural business, the land is an asset in other ways: first, as a connection to previous generations of the farm family, second, it facilitates 'a bit of farming' by those with other jobs and, third, under recent planning policy it is a resource which enables past, current and possibly future generations to stay in (or return to) the home area. In addition to their own sweat equity skills, the extensive network of family, friends and neighbours associated with deep family roots in the area includes those with construction skills whom they can draw upon at 'mates' rates'. In short, to self-build on the family farm is the least expensive route into owner-occupation. Notably, while Northern Ireland's rural house building policy has varied over time, and is currently characterised by a comparatively more stringent approach than previously, none of our interviewees commented on this. This may be because the interview concentrated on staying processes (during which self-builds emerged as important) rather than on rural planning policy per se.

The staying/ immobility literature to date has failed to adequately study structural influences. At best, such influences are acknowledged but rarely researched. The contribution of this study has been to demonstrate that planning policy represents a significant structural enabler on staying. This finding, however, raises important questions which are worthy of further investigation. Is living (or staying) in the Northern Irish countryside becoming the preserve of existing farm families? Might a Northern Irish variation of Gkartzios and Shucksmith's (2015) 'spatial apartheid' be emerging, whereby young adults from farm families have the option to stay in the countryside (via self-build) 
while those from non-farm families are required to move to settlements in order for their housing needs to be met? Considered from a different angle, namely that to self-build on family land represents the least expensive route into owner-occupation, might some who stay have done so only because of this housing advantage? There is no evidence of this from the interviews, but that is not to say that such reluctant stayers could emerge in a larger sample. A specific weakness of this pilot study is the small number of interviews undertaken. Nevertheless, as a structural influence on staying, further work could usefully explore the role of planning in the explicit delivery of sustainable rural communities. Given the normality of farm self-builds reported, a return to a wholesale presumption against residential development in the countryside, sometime in the future, could potentially undermine the sustainability of these farm communities. Finally, future studies should examine other potential structural influences on staying and immobility, such as, labour markets and service provision and draw on their associated literatures. We have demonstrated that individual agency, structural influences and the local context need to be combined for a more holistic understanding. Equally, we have highlighted the value of drawing on the rural, population and planning literatures to provide a more nuanced understanding of a contemporary demographic process.

\section{Acknowledgements}

The first author gratefully acknowledges the funding provided by the 2015 Jantina Tammes visiting Chair at Groningen University which enabled this project to be undertaken. Special thanks go to $\mathrm{Dr}$ Stephanie Palmer who undertook the interviews and to all our stayers who willingly afforded us the time to be interviewed.

Funding: University of Groningen Jantina Tammes visiting Chair fund 2015. 


\section{References}

Barcus, H. and Brunn, S., 2009. Towards a typology of mobility and place attachment in rural America. Journal of Appalachian Studies 15 (1/2), pp. 26-48.

Barcus, H. and Halfacree, K., 2018. An Introduction to Population Geographies: Lives across space. Routledge, London.

Bauman, Z., 1992. Soil, blood and identity. Sociological Review 40(4), pp. 675-701.

BBC News, 2006. Rural building a 'landscape acne'. Broadcast 12th April 2006.

Champion, T., and Shuttleworth, I., 2017. Is longer-distance migration slowing? An analysis of the annual record for England and Wales since the 1970s. Population, Space and Place 23(3), e2024. https://doi.org/10.1002/psp.2024.

Clark, W.A.V. and Lisowski, W., 2019. Unpacking the Nature of Long-Term Residential Stability. In: Franklin, R. (Ed) Population, Place, and Spatial Interaction. New Frontiers in Regional Science: Asian Perspectives, vol 40. Springer: Singapore. https://doi.org/10.1007/978-981-13-9231-3_8.

Clark, W. A. V., Duque-Calvache, R. and Palomares-Linares, I., 2017. Place attachment and the decision to stay in the neighbourhood. Population, Space and Place 23(2). DOI:10.1002/psp.2001.

Clinch, P., Convery, F. and Walsh, B., 2002. After the Celtic Tiger, Challenges Ahead, O'Brien Press, Dublin.

Cockcroft, W. H., 1978. Review of Rural Planning Policy. Department of the Environment (NI), Belfast.

Cooke, T. J., 2011. It is not just the economy: Declining migration and the rise of secular rootedness. Population, Space and Place, 17(3), pp. 193-203. https://doi.org/10.1002/psp.670.

Coulter, R., van Ham, M., and Findlay, A., 2016. Re-thinking residential mobility: Linking lives through time and space. Progress in Human Geography 40(3), pp. 352-374, https://doi.org/10.1177/0309132515575417.

Cresswell, T., 2012. Mobilities II: Still. Progress in Human Geography 36(5), pp. 645-653. https://doi.org/10.1177/0309132511423349

Department of Environment, 1976. Residential Development in Rural Areas, HMSO, Belfast.

Department of Environment, 1978. Policy for the Control of Development in Rural Areas, HMSO, Belfast.

Department of Environment, 1993. Planning Strategy for Rural Northern Ireland, Belfast.

Department of Environment, 2007. Sustainable Development in the Countryside: Draft Planning Policy Statement 14, Belfast.

Department of Environment, 2008. Sustainable Development in the Countryside: Planning Policy Statement 21, Belfast. 
Department of Environment, 2015. Strategic Planning Policy Statement for Northern Ireland (SPPS) Planning for Sustainable Development, Belfast.

Fernandez-Carro, C. and Evandrou, M., 2014. Staying put; factors associated with ageing in one's 'lifetime home'. Insights from the European context. Research on Ageing and Social Policy, 2(1), 28-56. DOI: 10.17583/rasp.2014.1053.

Fischer, P., Holm, E., Malmberg, G. and Straubhaar, T., 2000 Why do people stay? Insider advantages and immobility. Hamburg Institute of International Economics Discussion Paper 112.

Fisher, P. and Malmberg, G., 2001. Settled people don't move: On life course and (im)mobility in Sweden. International Journal of Population Geography 7, pp. 357-371.

Gallent, N. and Scott, M., 2019. Housing and Sustainable Rural Communities. In Scott, M., Gallent, N. and Gkartzios, M., Editors, The Routledge Companion to Rural Planning, Routledge, London.

Geist, C. and McManus, P., 2008. Geographical mobility over the life course: motivations and implications. Population, Space and Place 14, pp.283-303. DOI: 10.1002/psp.508

Gkartzios, M. and Scott, M., 2010. Residential Mobilities and House Building in Rural Ireland: Evidence from Three Case Studies. Sociologia Ruralis 50(1), pp. 64-84. doi:10.1111/j.1467-9523.2009.00502.x

Gkartzios, M. and Shucksmith, M., 2015. 'Spatial anarchy' versus 'spatial apartheid': rural housing ironies in Ireland and England. Town Planning Review 86(1), pp.53-72. doi:10.3828/tpr.2015.4.

Hall, P., 1974. The Containment of Urban England. The Geographical Journal 140(3), pp. 386-408.

Haartsen, T. and Stockdale, A., 2018. S/elective belonging: how rural newcomer families with children become stayers. Population, Space \& Place. https://doi.org/10.1002/psp.2137

Haukanes, H., 2013. Belonging, mobility and the future: Representations of space in the life narratives of young rural Czechs. Young: Nordic Journal of Youth Research 21(2), pp. 193-210. https://doi.org/10.1177/1103308813477467.

Heenan, D., 2011. How local interventions can build capacity to address social isolation in dispersed rural communities: A case study from Northern Ireland. Ageing International 36, pp. 475-491.

Hidalgo, C. and Hernandez, B., 2001. Place attachment: Conceptual and empirical questions. Journal of Environmental Psychology 21(3), pp. 273-281.

Hjälm, A. ,2014. The 'Stayers': Dynamics of lifelong sedentary behaviour in an urban context. Population, Space and Place 20(6), pp. 569-580. https://doi.org/10.1002/psp.1796.

Hunter, W., 1987. Agriculture, forestry, fishing. In Buchanan, R. and Walker, B., Editors, Province, City and People: Belfast and its Region, Greystone Books, Antrim.

Johansson, M., 2016. Young women and rural exodus - Swedish experiences. Journal of Rural Studies 43, pp. 291-300. https://doi.org/10.1016/j.jrurstud.2015.04.002 
Johnston, R.J., 1971. Resistance to migration and the mover/stayer dichotomy: Aspects of kinship ad population stability in an English rural area. Geografiska Annaler B: Human Geography 53(1), pp. 16-27.

Kanakis, K., McShane, C.J., Kilcullen, AM.L. and Swinbourne, A.L., 2019. 'It's the people that keep me here': Exploring the role of community attachment in increasing length of residency. Journal of Rural Studies 70, pp. 19-25. https://doi.org/10.1016/j.jrurstud.2019.08.006

Kuhmonen, T., Kuhmonen, I. and Luoto, L., 2016. How do rural areas profile the future dreams by the Finnish youth? Journal of Rural Studies 44, pp. 89-100. https://doi.org/10.1016/j.jrurstud.2016.01.010

Leopold, T., Geissler, F. and Pink, S., 2012. How far do children move? Spatial distances after leaving the parental home. Social Science Research 41(4), pp. 991-1002. https://doi.org/10.1016/j.ssresearch.2012.03.004.

Lewicka, M., 2011. Place attachment: how far have we come in the last 40 years. Journal of Environmental Psychology 31(3), pp. 207-230. https://doi.org/10.1016/j.jenvp.2010.10.001.

Looker, D. and Naylor, T., 2009. 'At risk' of being rural? The experience of rural youth in a risk society. Journal of Rural and Community Development 4(2), pp. 39-64.

Matthew, R. H., 1964. Belfast Regional Survey and Plan. HMSO, Belfast.

Mellander, C., Florida, R. and Stolarick, K., 2011. Here to stay - the effects of community satisfaction on the decision to stay. Spatial Economic Analysis 6(1), pp. 5-24. https://doi.org/10.1080/17421772.2010.540031.

Michielin, F. and Mulder, C., 2008. Family events and the residential mobility of couples. Environment and Planning A 40(11), pp. 2770-2790. doi:10.1068/a39374

Morse, C. and Mudgett, J., 2018. Happy to be home: Place-based attachments, family ties, and mobility among rural stayers. The Professional Geographer 70(2), pp. 261-269. https://doi.org/10.1080/00330124.2017.1365309.

National Planning Policy Framework, 2019. Ministry of Housing, Communities and Local Government, London.

Ni Laoire, C. and Stockdale, A., 2016. Migration and the Life Course in Rural Settings. In International Handbook of Rural Studies, Shucksmith, M. and Brown, D., editors, Routledge, London.

Nugin, R., 2014. 'I think they should go. Let them see something'. Journal of Rural Studies 34, pp. 51-64. https://doi.org/10.1016/j.jrurstud.2014.01.003

Petrin, R., Schafft, K. and Meece, J., 2014. Educational sorting and residential aspirations among rural high school students: What are the contributions of schools and educators to rural brain drain? American Educational Research Journal, 51(2), 294-326. https://doi.org/ 10.3102/0002831214527493.

Relph, E., 1976. Place and Placelessness. Pion Limited, London. 
Rérat, P., 2014. The selective migration of young graduates: Which of them return to their rural home region and which do not? Journal of Rural Studies 35, pp. 123-132. https://doi.org/10.1016/j.jrurstud.2014.04.009.

Roin, A., 2015. The multi-faceted notion of home: Exploring the meaning of home among elderly people living in the Faroe Islands. Journal of Rural Studies 39, pp. 22-31. https://doi.org/10.1016/j.jrurstud.2015.03.002.

Rye, J., 2011. Youth migration, rurality and class: A Bourdieusian approach. European Urban and Regional Studies 18(2), pp. 170-183. https://doi.org/10.1177/0969776410390747.

Savage, M., 2010. The politics of elective belonging. Housing, Theory and Society 27(2), pp. 115-161.

Savage, M., Bagnall, G. and Longhurts, B., 2005. Globalization and Belonging. Sage, London.

Scott, M., 2019. Spatial planning and the rural economy. In: Scott, M., Gallent, N. and Gkartzios, M., Editors. The Routledge Companion to Rural Planning. Routledge, London.

Scott, M. and Murray, M., 2009. Housing rural communities: Connecting rural dwellings to rural development in Ireland. Housing Studies 24(6), pp. 755-774. https://doi.org/10.1080/02673030903223138.

Shucksmith, M., 1981. No Homes for Locals? Gower Publishing Company, Farnborough.

Shucksmith, M., 2011. Exclusive Rurality: Planners as Agents of Gentrification. Planning Theory and Practice 12(4), pp. 605-611.

Sterrett, K., 2003. The countryside aesthetic and house design in Northern Ireland. In Greer, J. and Murray, M., Editors, Rural Planning and Development in Northern Ireland, Institute of Public Administration, Dublin.

Stockdale, A. and Haartsen, T., 2018. Editorial: Putting rural stayers in the spotlight. Population, Space \& Place. https://doi.org/10.1002/psp.2124

Stockdale, A. and Catney, G., 2014. A lifecourse perspective on urban-rural migration: The importance of the local context. Population, Space and Place 20(1), pp.83-98. https://doi.org/10.1002/psp.1758.

Stockdale, A., Theunissen, N. and Haartsen'T., 2018. Staying in a state of flux: A life course perspective on the diverse staying processes of rural young adults. Population, Space and Place. https://doi.org/10.1002/psp.2139.

Taylor, M., 2008. Living Working Countryside: The Taylor Review of Rural Economy and Affordable Housing. Department for Communities and Local Government, London.

Thissen, F., Droogleever Fortuijn, J., Strijker, D., and Haartsen, T., 2010. Migration preferences of rural youth in the Westhoek, Flanders and the Veenkoloniën, The Netherlands. Journal of Rural Studies 26(4), pp. 428-437. https://doi.org/10.1016/j.jrurstud.2010.05.001. 
Tucker, C., Sharp, E., Stracuzzi, N., Van Gundy, K. and Rebellon, C., 2013. Rural parents' messages to their adolescent sons and daughters to leave their home communities. Journal of Adolescence 36(5), pp. 963-970. doi-10.1016/j.adolescence.2013.07.013.

Ulster University, 2016. Northern Ireland Quarterly House Price Index. Q3 2016 Report Number 128.

Ulster University, 2007. Northern Ireland Quarterly House Price Index. Q2.

Wolfe, A.W., Black, L. and Welser, H., 2019. Sense of community and migration intentions among rural young professionals. Rural Sociology, pp.1-23. DOI: 10.1111/ruso.12289. 